\title{
ANALISIS CURRENT RATIO DALAM MENILAI KONDISI KOPERASI UNIT DESA SUMBER REZEKI DESA KEPENUHAN RAYA
}

\author{
oleh: \\ *) Muhammad Roziqon \\ **) Prima Audia Daniel \\ *)Dosen Universitas Pasir Pengaraian \\ **) Dosen Tetap STIE Muhammadiyah Jambi
}

\begin{abstract}
Ringkasan
Analisis Current ratiountuk melihat bagaimana kondisi KUD Sumber Rezeki.Laporan keuangan KUD Sumber Rezeki yang terdiri dari Neraca dan Laporan Laba Rugi tahun 2010 sampai dengan tahun 2014. Data dalam penelitian ini diperoleh dengan melalui dokumentasi. Metode analisis deskriptif kuantitatif, yaitu metode pendekatan masalah berdasarkan angka untuk mengambil keputusan. Hasil penelitian menunjukkan bahwa Kinerja Keuangan KUD Sumber Rezeki Desa Kepenuhan Raya dilihat dari Current Ratio pada tahun 2010 sampai dengan 2014 dikatakan sangat baik karena nilai persentase lebih dari 200\% atau Current Ratio $>200 \%$-300\%.Pada tahun 2010 nilai persentase sebesar 239\%, tahun 2011 sebesar 288\%, tahun2012 sebesar 283\%, tahun 2013 253\%, dan tahun $2014229 \%$.
\end{abstract}

\section{Kata Kunci: Analisis, Current \& Ratio}

\section{Pendahuluan}

Analisis Fundamental yang mencakup analisis rasio keuangan, analisis kelemahan dan kekuatan di bidang finansial akan sangat membantu dalam menilai prestasi menajemen masa lalu dan prospeknya dimasa depan. Ada 4 analisis yang biasa dipergunakan dalam menilai prestasi sebuah lembaga diantaranya; rasio likuditas, aktivitas, laverage, dan profitabilitas. Current Ratio merupakan bagian dari analisis likuditas (Sartono,2010:113-138).

Lembaga koperasi di Indonesia memiliki peran ganda dan penting dalam struktur ekonomi, seperti membantu ekonomi rakyat, mewujudkan masyarkat yang bergotong royong dalam suatu sistem demokrasi di Indonesia. Ternyata peran ini sangat berhasil. Namun sangat tergantung kepada koperasi itu sendiri dan juga para anggotanya untuk saling membahu dalam mewujudkan keberhasilan lembaga. Efektif dan efisien mungkin pada segi peningkatan keuangan koperasi dan menyusun data tersebut dalam laporan keuangan.

Pada tingkat daerah peranan koperasi sudah digalakkan sejak lama, baik tingkat Provinsi, Kabupaten, Kecamatan maupun di tingkat Desa. Hal ini membuktikan bahwa keserasian lembaga ini terhadap masyarakat Indonesia sudah mendarah daging. Misalnya Kabupaten Rokan Hulu, walaupun kabupaten ini terbilang masih baru akan tetapi gerakan 
koperasi di daerah ini berkembang pesat. Salah satunya KUD Sumber Rezeki di Desa Kepenuhan Raya. Koperasi ini sudah berdiri sejak tahun 1999 dan mulai dipublikasikan pada awal tahun 2000. KUD diperkuat dengan 27 Kelompok Tani dan masing-masing kelompok tani rata-rata berjumlah 20 Kepala Keluarga. Jadi KUD mempunyai anggota 500 Kepala Keluarga. Jumlah Pengurus KUD sebanyak 11 orang. Masa jabatan Pengurus KUD 3 Tahun. Laporan pertanggungjawaban dilaksanakan 1 Tahun sekali yang di sebut Rapat Anggota Tahunan (RAT).

Koperasi ini bekerjasama dengan perusahaan yang bergerak pada perkebunan kelapa sawit. Dimana pihak Desa menyediakan lahan yang kemudian diolah dan ditanami oleh perusahaan dengan ketentuan yang sama-sama menguntungkan kedua belah pihak..

Berdasarkan Berdasarkan UU No. 25 Tahun 1992 Pasal 45 ayat 1, bahwa kegiatan koperasi dalam perkembangan di Indonesia tidak lepas dari peranan pemerintah. Koperasi merupakan salah satu kekuatan ekonomi yang tumbuh dan berkembang di kalangan masyarakat sebagai pendorong tumbuhnya perekonomian nasional sekaligus sebagai soko guru dalam perekonomian di Negara Indonesia. Terutama dalam masa pembangunan ini, bukan hanya di bidang perekonomian saja, akan tetapi lebih dari itu kompetensi diharapkan bisa menjadi alat pemersatu bagi seluruh rakyart Indonesia. Namun ternyata sumbangan, dan peranannya di dalam perekonomian nasional tersebut masih sangat terbatas.

Dalam tata cara umum, dalam penilaian kondisi keuangan suatu koperasi dapat kita ketahui melalui laporan keuangan koperasi yang terdiri dari laporan neraca, laporan perhitungan laba rugi, laporan perubahan kondisi keuangan koperasi yang bersangkutan. Dari laporan perubahan posisi keuangan tersebut, tercermin dari laporan sumber dan pengguna dana.

Perencanaan terhadap sumber dan penggunaan dana sangat diperlukan

karena banyak sekali penganalisa atau pihak-pihak lain yang berkepentingan yang menginginkan adanya laporan sumber dan pengguna dana tersebut, karena analisa sumber dan pengguna dana tersebut merupakan alat analisa keuangan yang sangat penting bagi finansial manajer untuk mengetahui perkembangan koperasi beserta kebutuhan pembelanjaannya dan untuk menentukan cara terbaik, untuk membiayai dan membelanjai kebutuhan tersebut.

Dalam laporan keuangan tersebut akan lebih penting dan bermanfaat bagi pihak-pihak yang berkepentingan, apabila data tersebut dapat diperbandingkan antara dua periode atau lebih untuk dianalisa yang akan dapat memberikan penilaian keadaan koperasi yang sebenarnya. Agar dapat mengetahui lebih jelas lagi mengenai posisi dan kekuatan-kekuatan yang telah dicapai dan kelemahan-kelemahan yang ditemui selama beberapa periode, maka laporan 
keuangan tersebut perlu dianalisa lebih lanjut. Dalam mengadakan analisa terhadap laporan keuangan dipergunakan alat-alat teknik analisa. Alat-alat analisa yang sering dipergunakan adalah analisa rasio antara lain rasio likuiditas, rasio solvabilitas, rasio rentabilitas dan rasio aktifitas juga rasio efektifitas dan efesiensi dari pada manajemen dan prospek koperasi dimasa depan.

Current Ratiomerupakan bagian dari rasio likuditas yang mengidikasikan tentang adanya pengaturan kebijaksanaan yang dapat mempertahankan kemampuan finansialnya yang segera dapat dipenuhi akan mengakibatkan kepercayaan anggota berkurang, karena hal ini dapat dianggap koperasi tidak mempunyai kemampuan yang cukup untuk dapat mengatasi kewajiban jangka pendeknya.

Berdasarkan gambaran diatas dapat diperoleh gambaran arti pentingnya seorang pimpinan koperasi untuk mengatur dan mengendalikan posisi keuangan agar koperasi tetap dalam kondisi yang likuid serta kemampuannya untuk mencapai laba yang optimal.

Berdasarkan kondisi tersebut, penulis menyajikan laporan keuangan KUD Sumber Rezeki Desa Kepenuhan Raya Kecamatan Kepenuhan Kabupaten Rokan Hulu pada 5 (lima) tahun terakhir. Terlihat perubahan, mulai dari tahun 2010 jumlah aktiva lancar Rp. 881.247.763, tahun 2011 jumlah aktiva lancar Rp. 1.126.791.240, tahun2012 jumlah aktiva lancar yaitu Rp.1.494.957.099, tahun 2013 jumlah aktivalancar Rp. 1.825.155.222, dan terakhir tahun 2014 jumlah aktiva lancar Rp.2.365.335.082. Pada tahun 2010 ke 2014 jumlah aktiva lancar terus mengalamikenaikan.

Disektor hutang lancar juga mengalami perubahan, pada tahun 2010 jumlah hutang lancar sebesar Rp.367.609.862, pada tahun 2011 jumlah hutang lancar mengalami kenaikan sebesar Rp.390.268.362, pada tahun berikutnya yaitu tahun 2012 jumlah hutang lancar juga mengalami kenaikan menjadi Rp.526.630.580, pada tahun 2013 jumlah hutang lancar terus mengalami kenaikan sebesar Rp.722.087.808, dan terakhir pada tahun 2014 jumlah hutang lancar juga terus mengalami kenaikan dengan jumlah hutang lancar sebesar Rp.1.029.133.033.

Jumlah aktiva KUD Sumber Rezeki Desa Kepenuhan Raya Kecamatan Kepenuhan Kabupaten Rokan Hulu dalam lima tahun terakhir ini juga mengalami perubahan, pada tahun 2010 jumlah aktiva sebesar Rp.1.014.749.715, pada tahun 2011 jumlah aktiva mengalami kenaikan menjadi Rp.1.260.293.192, pada tahun 2012 jumlah aktiva kembali naik menjadi Rp.1.653.296.767, pada tahun 2013 jumlah aktiva kembali naik menjadi Rp.1.971.975.731,dan pada tahun 2014 jumlah aktiva juga terus mengalami kenaikan sebesar Rp.2.519.656.025. 
Jumlah SHU bersih yang telah dicapai KUD Sumber Rezeki Desa Kepenuhan Raya Kecamatan Kepenuhan Kabupaten Rokan Hulu pada tahun 2010 sebesar Rp. 39.885.951, pada tahun 2011 SHU meningkat sebesar Rp.290.744.690. Begitu pula pada tahun 2012 SHU menunjukkan angka kenaikan yaitu Rp. 402.100.455, pada tahun 2013 SHU terus mengalami kenaikan yaitu dengan jumlah SHU sebesar Rp. 410.822.450, dan terakhir pada tahun 2014 SHU yang diperoleh KUD Sumber Rezeki mengalami peningkatan yaitu dengan jumlah SHU sebesara Rp. 481.227.000. Bila ditinjau dari ratio keuangan, maka ratio-ratio keuangan dari data tersebut akan terlihat bagaimana pergerakan current ratio seperti pada tabel berikut :

Tabel 1 Perbandingan Ratio Keuangan KUD Sumber Rezeki Desa Kepenuhan Raya Tahun 2010-2014

\begin{tabular}{|l|c|c|c|c|c|}
\hline $\begin{array}{l}\text { RATIO } \\
\text { LIKUIDITAS }\end{array}$ & 2010 & 2011 & 2012 & 2013 & 2014 \\
\hline Curren Ratio & $239 \%$ & $288 \%$ & $283 \%$ & $252 \%$ & $229 \%$ \\
\hline
\end{tabular}

Sumber: Data olahan 2015.

Dari tabel diatas dapat terlihat bahwa tingkat likuiditas (Current Ratio) mulai tahun 2010 yaitu sebesar 239\%, tahun 2011 sebesar 288\%, tahun 2012 tingkat likuiditasnya sebesar 283\%, tahun 2013 sebesar 252\% dan pada tahun 2014 sebesar 229\%. Dengan demikian dapat diketahui bahwa tingkat likuiditas dari tahun ketahun naik turunnya tidak seimbang. Pada tahun 2010 ketahun 2011 terjadi kenaikan, kemudian pada tahun 2011 ke 2012 ratio terjadi penurunan, kemudian tahun 2013 juga terjadi penurunan kembali, dan pada tahun 2014 juga mengalami penurunan. Kenaikan dan penurunan tingkat likuiditas yang terjadi pada KUD Sumber Rezeki tidak merata tetapi juga naik dan turun tidak stabil. Ratio keuangan yang perlu dipertahankan atau dicapai dalam arti keuangan yang baik adalah likuiditas sebesar $200 \%$. Adapun tujuan penelitian adalah untuk menganalisis Current Ratio pada Koperasi Unit Desa Sumber Rezeki Desa Kepenuhan Raya tahun 2010-2014.

\section{Tinjauan Pustaka}

\section{Kinerja Keuangan}

Salah satu kinerja keuangan adalah gambaran setiap hasil ekonomi yang diraih oleh perusahaan pada periode tertentu melalui aktivitas-aktivitas perusahaan untuk menghasilkan keuntungan efisien dan efektif, yang dapat diukur perkembangannya dengan menganalisis data-data keuangan yang tercermin dalam laporan keuangan. 
Pengukuran kinerja digunakan perusahaan untuk melakukan perbaikan diatas kegiatan operasionalnya agar dapat bersaing dengan perusahaan lain. Analisis kinerja keuangan merupakan proses pengkajian secara kritis terhadap review data, menghitung, mengukur, menginterpretasikan, dan memberi solusi terhadap keuangan perusahaan pada suatu periode tertentu.

Menurut Wibowo (2007:7) manajemen kinerja keuangan adalah manajemen tentang menciptakan hubungan dan memastikan komunikasi yang efektif.Kinerja merupakan hasil pekerjaan yang mempunyai hubungan kuat dengan tujuan strategis organisasi, kepuasan konsumen, dan memberikan kontribusi pada ekonomi.Dengan demikian kinerja keuangan suatu perusahaan dapat dikatakan baik bila telah menunjukan kontribusi yang baik bagi perusahaan.

Menurut Rivai dan Ella (2009: 604) kinerja adalah suatu tampilan secara utuh atas perusahaan dalam periode waktu tertentu, merupakan hasil atau prestasi yang mempengaruhi kegiatan operasional perusahaan dalam memanfaatkan sumber-sumber daya yangdimiliki.

Menurut Bastian (2007:52) kinerja keuangan adalah gambaran pencapaian pelaksanaan suatu kegiatan/program/kebijaksanaan dalam mewujudkan sasaran, tujuan, misi, dan visi organisasi.Secara umum kinerja menunjukkan prestasi yang dicapai oleh organisasi dalam periode tertentu.

Menurut Fahmi (2013:239) kinerja keuangan adalah suatu prestasi yang dilakukan untuk melihat sejauh mana suatu perusahaan telah melakukan dengan menggunakan aturan-aturan pelaksanaan keuangan secara baik danbenar. Kinerja keuangan merupakan gambaran dari pencapaian keberhasilan perusahaan, dapat diartikan sebagai hasil yang telah dicapai atas berbagai aktivitas yang telah dilakukan.

Kinerja keuangan adalah untuk menilai kondisi keuangan dan prestasi perusahaan, analisis memerlukan beberapa tolak ukur yang digunakan yaitu rasio dan indeks, yang menghubungkan dua data keuangan antara satu dengan yang lain (Fahmi, 2013: 67).

Selanjutnya, menurut Mulyadi (2007: 2 dalamLaila, 2014) menguraikan pengertian kinerja keuangan ialah penentuan secara periodik efektifitas operasional suatu organisasi dan karyawannya berdasarkan sasaran, standar, dan kriteria yang ditetapkan sebelumnya.

Pendapat Fahmi (2012: 3) menjelaskan bahwa tahap-tahap dalam menganalisis kinerja keuangan suatu perusahaan secara umum yaitu :

a. Melakukan review terhadap laporan keuangan. Review disini dilakukan dengan tujuan 
agar laporan keuangan yang sudah dibuat tersebut sudah sesuai dengan penerapan kaidah-kaidah yang berlaku umum dalam dunia akuntansi, sehingga dengan demikian hasil laporan keuangan tersebut dapat dipertanggung jawabkan.

b. Melakukan perhitungan. Penerapan metode perhitungan disini adalah disesuaikan dengan kondisi dan permasalahan yang sedang dilakukan sehingga hasil dari perhitungan tersebut akan memberikan suatu kesimpulan sesuai dengan analisis yang diinginkan.

c. Melakukan perbandingan terhadap hasil hitungan yang telah diperoleh, dari hasil hitungan yang sudah diperoleh tersebut kemudian dilakukan perbandingan dengan hasil hitungan dari berbagai perusahaan lainnya.

d. Melakukan penafsiran terhadap berbagai permasalahan yang ditemukan. Pada tahap ini analisis melihat kinerja keuangan perusahaan adalah setelah dilakukan ketiga tahap tersebut. Selanjutnya dilakukan penafsiran untuk melihat apa-apa saja permasalahan dan kendala-kendala yang dialami oleh perusahaan.

e. Mencari dan memberikan pemecahan masalah terhadap berbagai masalah yang ditemukan. Dicarikan solusi guna memberikan suatu input atau masukan agar apa yang menjadi kendala dan hambatan selama ini dapat terselesaikan.

Sehingga bisa disimpulkan bahwa kinerja keuangan adalah suatu prestasi yang dilakukan untuk melihat sejauh mana suatu perusahaan atau lembaga keuanga dalam pengelolaan yang dijalankan dengan menggunakan aturan-aturan yang telah baku dijalankan dengan baik danbenar.

\section{Analisis Rasio Keuangan}

Beberapa pendapat berkaitan dengan analisis rasio keuangan diantaranya;

Menurut pendapat Sartono (2010:113), bahwa analisis rasio keuangan sangat membatu dan megindikasikan prestasi yang telah dicatatkan oleh sebuah lembaga keuangan dalam menciptakan kemakmuran dan meminimalkan resiko yang akan dihadapi.

Analisis rasio adalah suatu cara untuk menganalisa laporan keuangan yang mengungkapkan hubungan matematik antara suatu jumlah dengan jumlah lainnya atau perbandingan antara satu pos dengan pos lainnya, sehingga dapat menjelaskan gambaran kepada penganalisa tentang baik buruknya keadaan atau posisi keuangan suatu perusahaan terutama apabila angka rasio tersebut dibandingkan dengan angka rasio pembanding yang digunakan sebagai standar (John, 2005). 
Selanjutnya menurut Sutrisno (2007:214) dalam bukunya Manajemen Keuangan yang dimaksud analisis rasio keuangan adalah menghubungkan elemen-elemen yang ada di laporan keuangan agar bisa di interprestrasikan lebih lanjut. Dengan demikian analisis rasio keuangan berguna untuk menentukan kesehatan atau kinerja keuangan perusahaan baik pada saat sekarang maupun dimasa mendatang sehingga sebagai alat untuk menilai posisi keuangan perusahaan dalam suatu periode tertentu.

\section{Rasio Lancar (Current Ratio).}

Rasio lancar (current ratio) adalah rasio yang membandingkan antara aktiva yang dimiliki perusahaan dengan hutang jangka pendek.Aktiva disini meliputi kas, piutang dagang, efek, persediaan, dan aktiva lancar lainnya. Sedangkan hutang jangka panjang meliputi hutang dagang, hutanng wesel, hutang bank.

Rasio ini menunjukkan sampai dimana hutang-hutang jangka pendek dapat dibayar dari aktiva yang dapat dijadikan uang pada waktu yang sama.Rumus untuk mencari rasio lancar (current ratio) adalah sebagai berikut :

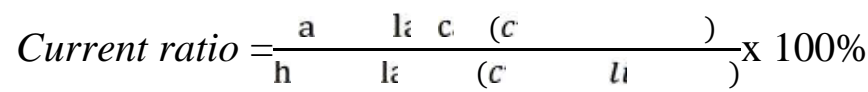

Secara umum rasio ini bisa dikatakan baik jika nilainya mencapai 2 atau $200 \%$ (Martono, 2002: 55-56).

Tabel 2 Standar perhitungan current ratio

\begin{tabular}{|c|c|c|c|}
\hline Komponen & Standar & Nilai & Kriteria \\
\hline \multirow{4}{*}{ Current Ratio } & $\geq 200 \%$ & 100 & Sangat Baik \\
\cline { 2 - 4 } & $175 \%-200 \%$ & 75 & Baik \\
\cline { 2 - 4 } & $150 \%-174 \%$ & 50 & Cukup Baik \\
\cline { 2 - 4 } & $125 \%-149 \%$ & 25 & Kurang Baik \\
\cline { 2 - 4 } & $<125 \%$ & 0 & Buruk \\
\hline
\end{tabular}

\section{Ruangan Lingkup Penelitian}

Ruang lingkup penelitian ini terbatas pada Koperasi Unit Desa Sumber Rezeki Desa Kepenuhan Raya. Laporan keuangan terbatas pada Koperasi Unit Desa Sumer Rezeki, kinerja keuangan terbatas pada wawancara oleh peneliti kepada pengelola Koperasi Unit Desa Sumber Rezeki Desa Kepenuhan Raya.

Waktu penelitian dimulai pada bulan Desember 2015 sampai bulan Januari 2016 adapun tempat penelitian di Koperasi Unit Desa Sumber Rezeki Desa Kepenuhan Raya. 


\section{A. Analisis Data Penelitian}

Laporan keuangan Koperasi Unit Desa (KUD) Sumber Rezeki Desa Kepenuhan Raya yang telah disajikan dalam neraca dan rugi laba selama lima tahun terakhir yaitu periode 20102014 yang telah melalui pengolaha data maka perhitungan analisis kinerja dari aspek likuiditas pada Koperasi Koperasi Unit Desa (KUD) Sumber Rezeki Desa Kepenuhan Raya dari perhitungan sebagai berikut:

\section{Deskripsi Hasil Penelitian}

Dalam pembahasan hasil penelitian ini akan dibahas mengenai bagaimana efektifitas kinerja keuangan yang dilakukan Koperasi Unit Desa Sumber Rezeki Desa Kepenuhan Raya dengan analisis rasio likuiditas dengan mengunakan current ratio, yang dilakukan terhadap laporan keuangan dari tahun 2010 sampai dengan 2014.

\section{Analisis Penelitian}

\subsection{Current Ratio}

Current ratio adalah rasio yang membandingkan antara aktiva yang dimiliki perusahaan dengan hutang jangka pendek.

Rumus yang digunakan adalah sebagai berikut:

$\frac{\text { aktiva lancar }\left(\begin{array}{cc}c & r_{i}\end{array}\right)}{\text { hutang lancar }\left(\begin{array}{lll}C & \text { en } & \text { li }\end{array}\right)} \times 100 \%$

$\begin{array}{rlll}\text { CR } 2010 & =\frac{8}{3} \quad .2 & .7 & .7 \\ & =239 \% & .8\end{array}$

Berdasarkan perhitungan diatas bahwa tahun 2010 dihasilkan rasio sebesar 239\%, ini menunjukan bahwa setiap Rp. 100 utang lancar dijamin dengan Rp. 239 aktiva lancar. Dilihat dari standar nilai rasio perusahaan nilai rasio tersebut masuk dalam kriteria sangat baik, karena memenuhi standarperusahaan.

$$
\begin{aligned}
& \text { CR } 2011=\frac{1.1 \quad .7 \quad .2}{3 \quad .2 \quad .3} \times 100 \% \\
& =288 \%
\end{aligned}
$$

Berdasarkan perhitungan diatas bahwa tahun 2011 dihasilkan rasio sebesar 288\%, ini menunjukan bahwa setiap Rp.100 utang lancar dijamin dengan Rp. 288 aktiva lancar. Dilihat dari standar nilai rasio perusahaan nilai rasio tersebut masuk dalam kriteria baik, karena memenuhi standarperusahaan.

$$
\begin{aligned}
\mathrm{CR} 2012 & =\frac{1.4 \quad .9 \quad .0}{5.6 .5} \times 100 \% \\
& =283 \%
\end{aligned}
$$

Berdasarkan perhitungan diatas bahwa tahun 2012 dihasilkan rasio sebesar 283\%, ini menunjukan bahwa setiap Rp.100 utang lancar dijamin dengan Rp. 283 aktiva lancar. Dilihat 
dari standar nilai rasio perusahaan nilai rasio tersebut masuk dalam kriteria baik, karena memenuhi standarperusahaan.

$\begin{aligned} \mathrm{CR} 2013 & =\frac{1.9 \quad .9 \quad .2}{7} \quad .0 \quad .8 \\ & =263 \% 100 \%\end{aligned}$

Berdasarkan perhitungan diatas bahwa tahun 2013 dihasilkan rasio sebesar 263\%, ini menunjukan bahwa setiap Rp. 100 utang lancar dijamin dengan Rp. 263 aktiva lancar. Dilihat dari standar nilai rasio perusahaan nilai rasio tersebut masuk dalam kriteria sangat baik, karena memenuhi standarperusahaan.

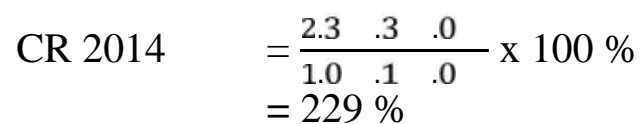

Berdasarkan perhitungan diatas bahwa tahun 2014 dihasilkan rasio sebesar 229\%, ini menunjukan bahwa setiap Rp. 100 utang lancar dijamin dengan Rp. 229 aktiva lancar. Dilihat dari standar nilai rasio perusahaan nilai rasio tersebut masuk dalam kriteria sangat baik, karena memenuhi standarperusahaan.

\section{Pembahasan}

Berdasarkan analisis data keuangan yang dilakukan, maka diperoleh informasi bahwa dilihat dari: Current Ratio, dari pertumbuhan current ratio yang terjadi pada Koperasi Unit Desa Sumber Rezeki Desa Kepenuhan Raya selama lima tahun terakhir dapat diketahui bahwa current ratio sudah diatas standar yaitu sudah diatas $200 \%$. Hanya pada tahun 2009 KUD mengalami begitu besar peningkatan current ratio. Hal ini disebabkan oleh peningkatan aktiva lancar yang standar. Semakin tinggi Current Ratio semakin tinggi pula tingkat keamanan KUD tersebut. Dan Current Ratio ini akan tinggi bila aktiva lancar lebih besar nilainya bila dibandingkan dengan hutang lancar. Namun sebaliknya, bila nilai Current Ratio rendah akan mengurangi keamanan KUD. Oleh sebab itu KUD harus dapat memaksimalkan nilai aktiva lancar dan menekan nilai hutang lancar. Hal ini dapat dilakukan antara lain dengan menjual aktiva tetap, mendapatkan tambahan modal sendiri ataupun menambah hutang jangka panjang. Menambah hutang jangka panjang sebenarnya akan menambah kewajiban KUD akan tetapi hutang jangka panjang jangka waktu pengembaliannya relatif lebih lama, sehingga akan memberikan kelonggaran bagi KUD. 


\section{Kesimpulan}

Kesimpulan dari penelitian ini adalah bahwasecara umum, kinerja keuanganKoperasi Unit Desa Sumber Rezeki Desa Kepenuhan Raya tahun 2010-2014 berdasarkan liquiditas adalah baik. Secara terperinci, curent ratio Koperasi Unit Desa Sumber Rezeki adalah Baik. Hal ini dikarenakan curent ratio dari tahun ke tahun sejak 2010-2014 > 200\%. Berdasarkan Cash Ratio adalah tidak Baik, karena Cash Ratio sejak tahun 2010-2014 terus mengalami penurunan, sedangkan berdasarkan quick ratio adalah baik. Hal ini dikarenakan quick ratio sejak tahun 2010-2014> 200\%.

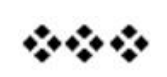

\section{DAFTAR PUSTAKA}

Amstrong, M. dan Baron, A. 1998. Manajemen Kinerja-Realitas Baru. London: Institute of Personalia dan Pembangunan.

Adi Kusumo Yulianto, 2008. “Analisis Kinerja Keuangan Bank Syariah Mandiri Periode 20022007”. Jurnal Ekonomi Islam, Vol. II, No. 1, Juli.

Bastian, Indra. 2006. Sistem Akuntansi Sektor Publik. Jakarta. Selemba Empat.

Bastian, 2007. Kinerja Keuangan. Jakarta: Pers. 2010. Kinerja Keuangan. Jakarta: Pers.

Fahmi, Irham. 2012. Analisis Kinerja Keuangan. Bandung: PT. Gramedia Pustaka Utama.

Husnah, Asmaul. 2010. Peranan Koperasi Agro Niaga (Kan) Jabung Malang Dalam Meningkatkan Kesejahteraan Sosial Ekonomi Petani Susu Di Jabung. Skripsi. Malang: Universitas Islam Negeri Maulana Malik Ibrahim.

Jumingan, 2006. Analisis Laporan Keuangan, Cetakan Pertama, PT Bumi Aksara, Jakarta.

Kementerian Negara Koperasi dan Usaha Kecil Menengah Republik Indonesia. (2006), Peraturan Menteri Negara Koperasi dan Usaha Kecil dan Menengah Republik Indonesia Nomor 06/Per/M.KUKM/V/2006 Tentang Pedoman Penilaian Koperasi Berprestasi. Jakarta: Kementerian KUKM RI.

Kasmir, 2010. Pengantar Manajemen Keuangan. Kencana Prenada Media Grup : Jakarta. 2013. Analisis Laporan Keuangan. Jakarta : Rajawali Pers.

Kusumo, Yunanto Adi.2008."Analisis Kinerja Keuangan Bank Syariah Mandiri Periode 20022007(Pendekatan PBI No.9/1/PBI/2007).Jurnal Ekonomi Islam, Vol.II. No.(1) Purwanti, Endang.2010.’Pengaruh Pangsa Pasar, Rasio Leverage, Intensitas Modal Terhadap 
Profitabilitas Koperasi Simpan Pinjam di Salatiga”.Jurnal - Among Makarti, Vol. (3) No.(5).

Laporan Keuangan Tahunan Koperasi Unit Desa Sumber Rejeki Desa Kepenuhan Raya 2012 2014.

Mahmudi, 2010, Manajemen Kinerja Sektor Publik, UPP STIM YKPN, Yogyakarta.

Martono. 2002. “Manajemen Keuangan”, Edisi Pertama. Yogyakarta : Ekonosia.

Muljono, Djoko. 2012. Pengaruh Perpajakan pada Penerapan Standar Akuntansi Keuangan Entitas Tanpa Akuntabilitas Publik. Penerbit ANDI. Jakarta. 418 hlm.

Munizu, Musran.2010.’Pengaruh Faktor-Faktor Eksternal dan Internal Terhadap Kinerja Usaha Mikro dan Kecil (UMK) di Sulawesi Selatan".Jurnal Manajemen dan Kewirausahaan. Vol.12. No.(1). Hal :33-41

Munawir, S. 2010. Analisis Laporan Keuangan. Yogyakarta :Liberty.

Rivai \& Ella. 2009. Kinerja Keuangan. Jakarta: Jakarta Pers.

Sartono, R.Agus.2010.Manajemen Keuangan Teori dan Aplikasi Edisi 4.Penerbit BPFE Yogyakarta. Hal:113-138.

Ulupui I G. K. A., (2007). Analisis Pengaruh Rasio Likuiditas, Leverage, Aktivitas, dan Profitabilitas Terhadap Return Saham (Studi pada Perusahaan Makanan dan Minuman Dengan Kategori Industri Barang Konsumsi di BEJ), Jurnal Ilmiah Akuntansi dan Bisnis, 2(1): 1-20.

Undang- Undang Nomor 95 Tentang Koperasi.

Wibowo (2011). Manajemen Kinerja. Jakarta. PT. Raja Grapindo Persada.

Wibowo. 2007. Manajemen Kinerja. Jakarta: Raja Wali Pers.

Widiyanti, Ninik. 2010. Manajemen Koperasi. Jakarta : PT. Rineka Cipta 